\title{
Bioleaching kinetics of trace metals from coal ash using Pseudomonas spp.
}

\author{
Denvert Pangayao ${ }^{1,2, *}$, Michael Angelo Promentilla ${ }^{2}$, Susan Gallardo ${ }^{2}$, and Eric van Hullebusch ${ }^{3}$ \\ ${ }^{1}$ Chemical Engineering Department, Pamantasan ng Lungsod ng Maynila, Manila, Philippines \\ ${ }^{2}$ Chemical Engineering Department, De La Salle University,Manila, Philippines \\ ${ }^{3}$ Department of Environmental Engineering and Water Technology, UNESCO-IHE Institute for Water Education, Delft, The \\ Netherlands
}

\begin{abstract}
The kinetics of bioleaching of chromium, copper, manganese and zinc from coal ash using Pseudomonas spp. isolated from coal ash pond was investigated. From the previous study, parameters used for bioleaching were $1 \%$ pulp density, $90 \mathrm{rpm}, 37^{\circ} \mathrm{C}$ and $5 \mathrm{ml}$ inoculum was placed in a $100 \mathrm{ml}$ fresh medium with the ash. These conditions were used for bioleaching of coal ash for 30 days. Moreover, the initial $\mathrm{pH}$ of the solution is 8.20 and decreases to 8.61 . After 30 days of bioleaching, the maximum metal leached were $13.77 \%$ $\mathrm{Cr}, 14.61 \% \mathrm{Cu}, 6.33 \% \mathrm{Mn}$ and $12.18 \% \mathrm{Zn}$. Assuming that the coal ash will shrink uniformly with respect to time using Shrinking Core Model, the kinetic data showed linear plot for percent metal leached versus time, suggested that diffusion through ash layer control was the rate controlling mechanism.
\end{abstract}

\section{Introduction}

Coal is the most abundant, affordable and easy to transport and store fossil fuel used in the world. Coal is still the major source of raw material for power and heat generation [1-2]. Upon the combustion of coal, $80 \%$ of fly ash and $20 \%$ of bottom ash were produced. As of today, more than $39 \%$ of the world's global electricity is produced using coal with an annual production of 800 million tons of coal ash [3-4].

According to the Department of Energy (2017), the Philippine consumed more than 20 million metric tons of coal wherein $47 \%$ were used by power plants for the production of electricity [5-6]. Due to increasing industrial and economic growth demand for electricity would increase, thus, increasing production of coal ash is expected [4,7-8].

The common disposal method of coal ash is via ash pond or lagoons that pose significant health and environmental problems [9-10]. Since coal ash is produced in large quantities, it is considered as a secondary waste material that can be used in different applications such as road base construction, soil amendments and stabilizer, light weight aggregates, mine backfill, zeolite synthesis, fillers in polymer, adsorbent and scrubber, manufacture of construction materials, wastewater treatment and geopolymer [9-11].
In the technological era where metal is an important commodity, metal processing and recovery is focused in a low cost, environmental friendly method in developing this secondary waste material such as bioleaching [12-13]. Bioleaching is an innovative low-carbon and green technology, low cost and energy efficient technique for metal extraction from secondary waste material using microorganism via the production of organic and/or inorganic acids [12-15].

This research used Pseudomonas spp. which was isolated in a coal ash pond. The indigenous microorganism is a heterotrophic microbes that relies on organic compounds as a source of energy for their metabolism which results in the production of organic acids such as citric, gluconic and oxalic acid [13-14,16].

Kinetic study was used to analyze the mechanism of trace metals extraction via bioleaching process. The Shrinking Core Model is used to determine the rate controlling mechanism of the bioleaching process. Moreover, assuming that the coal ash is spherical, the material will shrink over time through bioleaching. Shrinking core model follows three scenarios namely: diffusion through the liquid film controls, diffusion through ash layers control and chemical reaction controls. Different studies were done using different secondary material such as: waste printed circuit board, spent refinery catalyst, copper smelter dust, sphalerite and spent hydro-processing catalyst [17-19]. However, mechanism for extraction of trace metals from coal ash has not been investigated.

${ }^{*}$ Corresponding author: $\underline{\text { dcpangayao } @ ~ p l m . e d u . p h ~}$ 
The focus of this study is to investigate the rate controlling mechanism using Shrinking Core Model of trace metal extraction from coal ash using Pseudomonas spp. Based on the previous study [20], optimum conditions were used in the bioleaching process to obtain maximum extraction of trace metals.

\section{Materials and methods}

\subsection{Coal ash from coal ash lagoon}

A combination of fly and bottom ash was used in the research was collected in the coal ash lagoon. The coal ash was provided by the private coal-fired power plant that uses Circulating Fluidized Bed (CFB) Boiler. The coal ash was oven dried at $105^{\circ} \mathrm{C}$ for 24 hours, passed though sieve \#200 mesh (0.075 microns) particle size. The particle size was held constant. The coal ash has a $\mathrm{pH}$ value of 10-11.5 making it alkali in nature.

\subsection{Microorganism}

The microorganism used in the experiment was Pseudomonas spp. This microorganism was indigenous in the coal ash pond in one of the power plants in the Philippines. Pseudomonas spp. was isolated by the University of the Philippines - Los Baños (UPLB), Department of Microbiology and identified using TaKaRa PCR thermal Cycler Dice TP600 at the Nakasaki Laboratory of Tokyo Institute of Technology (Tokyo, Japan).

\subsection{Growth of Pseudomonas spp.}

Pseudomonas spp. was cultured using a Nutrient Broth Medium consisting of $1 \mathrm{~g} / \mathrm{L}$ yeast, $2 \mathrm{~g} / \mathrm{L}$ peptone and $5 \mathrm{~g} / \mathrm{L}$ glucose. 8 grams of nutrient broth medium was dissolved in 1 liter of deionized water. The solution was autoclaved at $121^{\circ} \mathrm{C}$ for 15 minutes [21]. The resulting solution has a $\mathrm{pH}$ of 7.2. Then the inoculum was placed in a water bath shaker (Visio VS-1205SW1) at $90 \mathrm{rpm}$ and $37^{\circ} \mathrm{C}$. Pseudomonas spp. were incubated for 5 days prior to bioleaching [22-23].

\subsection{Bioleaching using Pseudomonas spp.}

The bioleaching experiment was done in a $250 \mathrm{~mL}$ Erlenmeyer flask with the following conditions: $1 \%$ pulp density ( $1 \mathrm{~g}$ of ash per $100 \mathrm{ml}$ medium), $90 \mathrm{rpm}$ and $37^{\circ} \mathrm{C}$. The solution was autoclaved at $121^{\circ} \mathrm{C}$ for 15 minutes and cooled. $5 \mathrm{ml}$ of the inoculum was placed in a $100 \mathrm{ml}$ fresh medium with the ash. The bioleaching experiment was for 30 days [24]. The extracted solution was filtered using a 0.45 micrometer cellulous acetate filter. Few drops of concentrated nitric acid were used to acidify the solution and stored at $4{ }^{\circ} \mathrm{C}$ prior to metal analysis using ICP-OES. The loss culture media was replenished every sampling. The experiment was done in duplicate runs. Table 1 shows the experimental model for the acquisition of data for Shrinking Core Model. This data will determine the controlling mechanism for bioleaching.

Table 1. Shrinking Core Model Experimental Run

\begin{tabular}{|c|c|}
\hline Days & \% Metal Leached \\
\hline 1 & \\
\hline 6 & \\
\hline 11 & \\
\hline 16 & \\
\hline 21 & \\
\hline 26 & \\
\hline 30 & \\
\hline
\end{tabular}

\subsection{Analytical methods}

X-ray Diffraction (XRD) analysis was performed using Bruker D8 Advance diffractometer equipped with copper radiation Sol-X detector $(\mathrm{CuK} \alpha, \lambda=0.15406 \mathrm{~nm})$. The data were recorded with a $1 \mathrm{~s}$ step time and $0.02^{\circ}$ scan step between $2^{\circ}$ to $80^{\circ}$. On the other hand, X-ray Fluorescence (XRF) analysis was conducted using Pananalytical Xflourescence spectrometer equipped with $150 \mathrm{eV}(\mathrm{Mn}$ $\mathrm{Ka})$ resolution Energy Dispersive Minipal 4 tube ( $\mathrm{Rh} \mathrm{X}$ Ray tube $-30 \mathrm{kV}-9 \mathrm{~W}$ ). All samples were dried at room temperature.

Also, metal analysis was done using Shimadzu AA6300 AAS analysis. Different wavelength were used namely: $267 \mathrm{~nm}$ for $\mathrm{Cr}, 324 \mathrm{~nm}$ for $\mathrm{Cu}, 257 \mathrm{~nm}$ for $\mathrm{Mn}$ and $213 \mathrm{~nm}$ for $\mathrm{Zn}$ were used to detect the concentration of the trace metals in the solution, reported as $\mathrm{mg} / \mathrm{kg}$ or $\mathrm{ppm}$. To preserve the samples, few drops of concentrated nitric acid was added.

\section{Results and Discussion}

\subsection{XRD: Mineralogical composition}

Figure 1 confirmed the mineral composition of the coal ash namely: quartz- $\mathrm{SiO}_{2}$, lime- $\mathrm{CaO}$, anhydrite, melilite, mullite, periclase, rutile and tricalcium aluminate. These minerals were detected by the different researchers [25-26].

\subsection{XRF: Elemental composition}

Table 2 shows the major and trace elements in the coal ash. The highest elemental composition is calcium which is accounted due to the addition of limestone prior to combustion process [27-28]. The mineralogical structure and elemental composition coincide with the XRD and XRF analyses. Furthermore, total metal contents in the ash 
are $0.96 \mathrm{mg} / \mathrm{kg} \mathrm{Zn}, 4.13 \mathrm{mg} / \mathrm{kg} \mathrm{Mn}, 0.81 \mathrm{mg} / \mathrm{kg} \mathrm{Cr}$ and $2.22 \mathrm{mg} / \mathrm{kg} \mathrm{Cu}$.

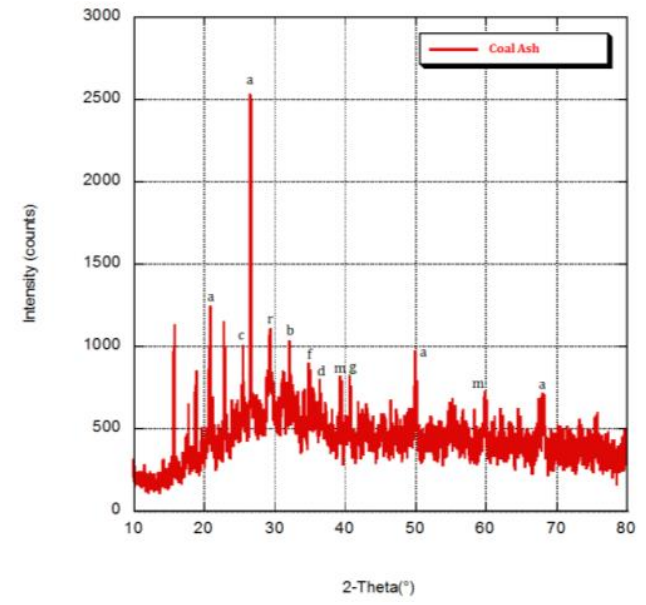

Fig. 1. XRD Analysis for Coal Ash (a: Quartz-SiO2, b: Melilite, 'c: Anhydrite, d: Tricalcium aluminate, f: Lime-CaO, g: Periclase, m: Mullite, r: Rutile).

Table 2. XRF analysis of ash samples.

\begin{tabular}{|c|c|}
\hline Element & $\%$ by weight \\
\hline Calcium & 39.46 \\
\hline Silicon & 25.70 \\
\hline Aluminum & 10.62 \\
\hline Iron & 6.20 \\
\hline Sulfur & 5.98 \\
\hline Sodium & 3.99 \\
\hline Chlorine & 2.11 \\
\hline Potassium & 1.83 \\
\hline Magnesium & 1.67 \\
\hline Titanium & 1.51 \\
\hline Strontium & 0.43 \\
\hline Barium & 0.22 \\
\hline Zirconium & 0.05 \\
\hline Tin & 0.035 \\
\hline Vanadium & 0.034 \\
\hline Chromium & 0.033 \\
\hline Nickel & 0.025 \\
\hline Manganese & 0.023 \\
\hline Tellurium & 0.021 \\
\hline Copper & 0.020 \\
\hline Zinc & 0.011 \\
\hline Bromine & 0.011 \\
\hline Yttrium & 0.007 \\
\hline
\end{tabular}

\subsection{Bioleaching experiment using Pseudomonas spp.}

At the start of the bioleaching experiment, the $\mathrm{pH}$ value is 8.20 and $0.88 \% \mathrm{Cr}, 0.96 \% \mathrm{Cu}, 0.52 \% \mathrm{Mn}$ and $0.71 \% \mathrm{Zn}$ were leached in the coal ash. After 30 days, the $\mathrm{pH}$ value increase to 8.61 with $13.77 \% \mathrm{Cr}, 14.61 \% \mathrm{Cu}, 6.33 \% \mathrm{Mn}$ and $12.18 \% \mathrm{Mn}$ were leached as seen in Figure 2. The final $\mathrm{pH}$ of the solution increased in the addition of the coal ash having high buffering capacity of the material and its toxicity to the bacteria in the presence toxic metals. The decrease in $\mathrm{pH}$ was due to the excreted metabolites, which include $\mathrm{H}^{+}$from organic acids, amino acids and other metabolites. These metabolites dissolve metals by displacement of metal ions from the solid materials by hydrogen ion or by the formation of soluble metal complexes and chelates. Moreover, the bacteria undergo microbial oxidation which resulted in the production of organic acids that plays an important role in the environmental mobility of the metal ions [29-30].

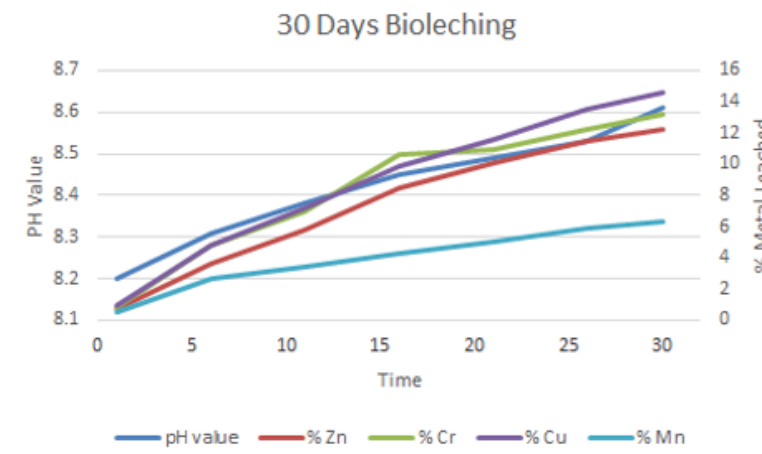

Fig. 2. $\mathrm{pH}$ profile vs. percent metal leached after 30 days bioleaching.

\subsection{Bioleaching kinetics: Shrinking core model}

From the previous study [20], the optimum parameter obtained were $1 \%$ pulp density, speed of $90 \mathrm{rpm}$ at $37^{\circ} \mathrm{C}$ and $5 \mathrm{~mL}$ initial inoculum. After 30 days of bioleaching, the maximum trace metal extracted were $13.77 \% \mathrm{Cr}$, $14.61 \% \mathrm{Cu}, 6.33 \% \mathrm{Mn}$ and $12.18 \% \mathrm{Mn}$. For the extraction of zinc, chromium, copper and manganese using Pseudomonas spp. follows the different shrinking core equations:

$$
\begin{gathered}
\frac{\mathrm{t}}{\tau}=1-\left(\frac{r_{c}}{R}\right)^{3}=X_{B} \\
\frac{\mathrm{t}}{\tau}=1-3\left(1-\mathrm{X}_{\mathrm{B}}\right)^{2 / 3}+2\left(1-\mathrm{X}_{\mathrm{B}}\right) \\
\frac{\mathrm{t}}{\tau}=1-\frac{\mathrm{r}_{\mathrm{c}}}{\mathrm{R}}=1-\left(1-\mathrm{X}_{\mathrm{B}}\right)^{1 / 3}
\end{gathered}
$$

Eq. 1 follows the diffusion through the liquid film control. Then Eq. 2 follows the diffusion through ash layers control and Eq. 3 follows the chemical reaction controls. 
Figs. 3-6 show the bioleaching kinetics of chromium, copper, manganese and zinc. Based on the result, diffusion though ash layers control is the rate determining step in all of the metal extracted. The $\mathrm{R}^{2}$ values are $0.9718,0.9873$, 0.9928 and 0.9844 for chromium, copper, manganese and zinc respectively. This can be associated by the production of biofilms and organic complexing agent of Pseudomonas spp. that can interfere in the bioleaching process. The extraction of the trace metals in the surface of the coal ash diminishes as the formation of biofilm increases over time. Moreover, the penetration of the organic acid produced by the bacteria decreases due to this interference [30-31].

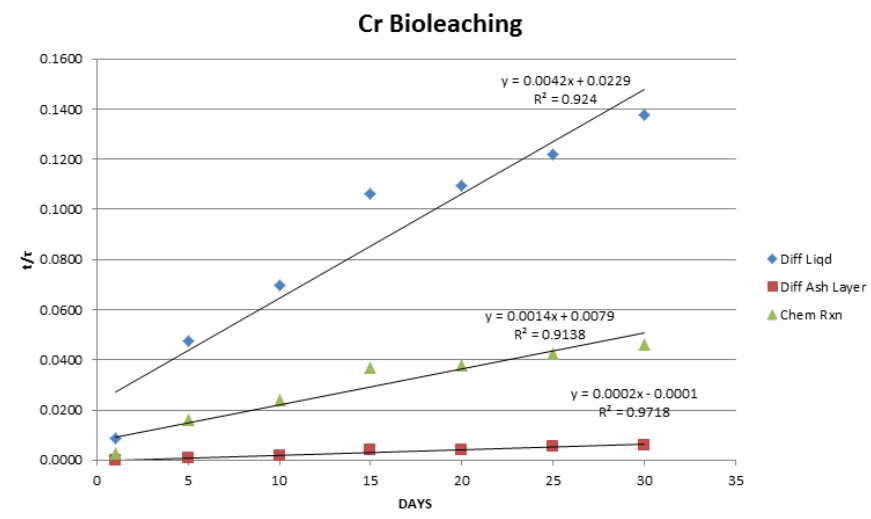

Fig. 3. Shrinking core model for $\mathrm{Cr}$ bioleaching.

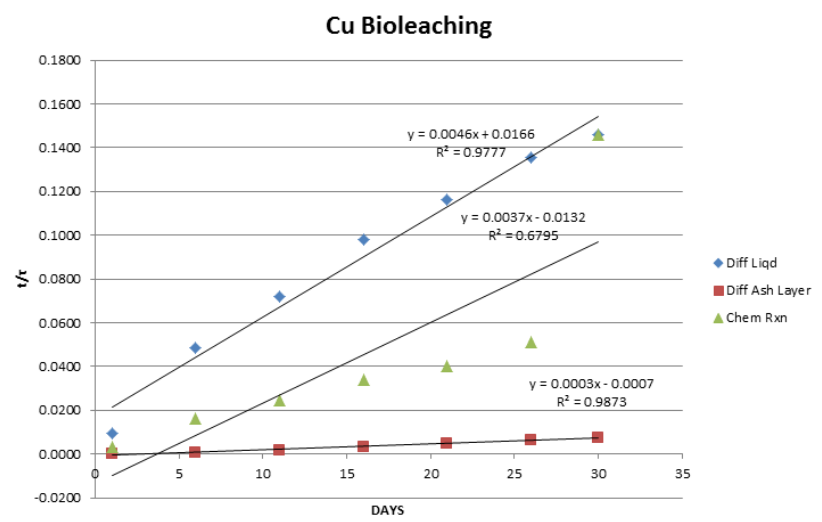

Fig. 4. Shrinking core model for $\mathrm{Cu}$ bioleaching.

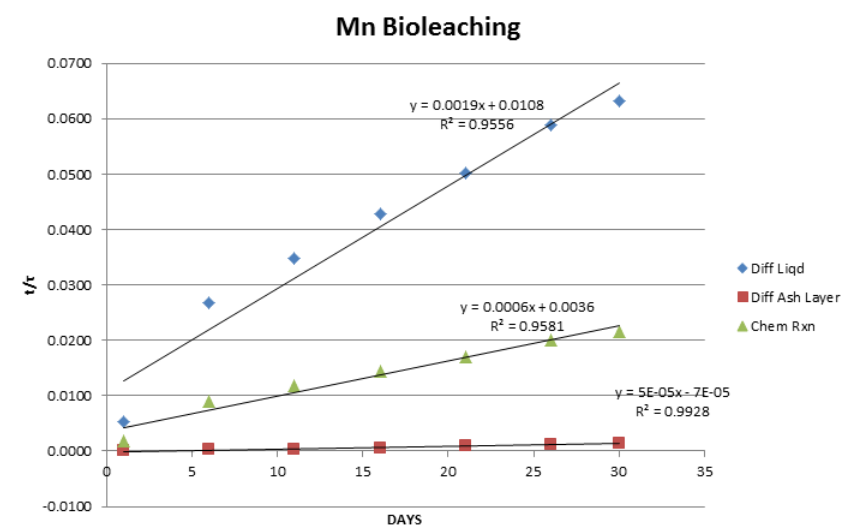

Fig. 5. Shrinking core model for Mn bioleaching.

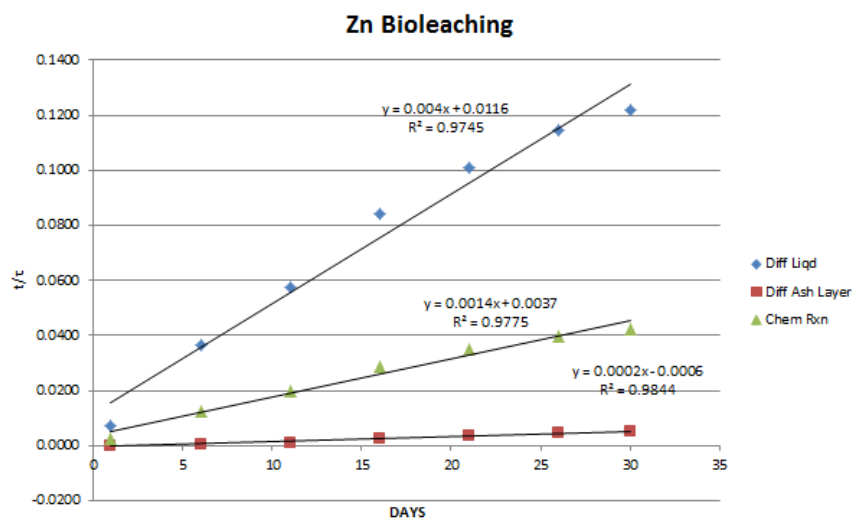

Fig. 6. Shrinking core model for Zn bioleaching.

\section{Conclusion}

Bioleaching kinetics of coal ash using Pseudomonas spp. was investigated. Total metal content, mineral and elemental composition was determined using ICP-OES, XRD and XRF respectively. Based on the result, the total metal contents of the coal ash are $0.81 \mathrm{mg} / \mathrm{kg} \mathrm{Cr}, 2.22$ $\mathrm{mg} / \mathrm{kg} \mathrm{Cu}, 4.13 \mathrm{mg} / \mathrm{kg} \mathrm{Mn}$ and $0.96 \mathrm{mg} / \mathrm{kg} \mathrm{Zn}$. Also, the minerals detected are quartz-SiO2, lime- $\mathrm{CaO}$, anhydrite, tricalcium aluminate, periclase, melilite, mullite and rutile and the major elemental composition are calcium, silicon, aluminum, iron and sulfur with conincide with the XRD result. High calcium oxide contributed to the alkalinity of the ashes. Using the optimum parameters, percent metal leached and rate controlling mechanism were determined. After 30 days of bioleaching, the maximum trace metal extracted were $13.77 \% \mathrm{Cr}, 14.61 \% \mathrm{Cu}, 6.33 \% \mathrm{Mn}$ and $12.18 \% \mathrm{Mn}$. And the $\mathrm{pH}$ value increased from 8.20 to 8.61 after 30 days bioleaching. Based on the Shrinking core model the rate controlling mechanism for all metal leached is diffusion though ash layers control.

This research is funded by Engineering Research and Development for Technology (ERDT) - Department of Science and Technology (DOST), Philippines, Campus France, Republic of France, Japan International Cooperation Agency (JICA) Project Office for the ASEAN University Network/Southeast Asia Engineering Education Development Network (AUN/SEED-Net) under the Collaborative Research Program for Common Regional Issues (CRC) with De La Salle University. Furthermore, we would like to thank the partner coal fired power plant and Tokyo Institute of Technology, Tokyo, Japan. Also, we like to thank the private coal fired power plant and Ile de France Region for the ICP-OES analysis. 


\section{References}

[1] Xu, J., Dai, J., Xie, H. and Lv, C. Coal utilization eco-paradigm towards an integrated energy system, Energy Policy, 109, 2017, 370-381.

[2] Guan, G. Clean coal technologies in Japan: A review, Chinese Journal of Chemical Engineering, 25, 2017, 689-697.

[3] Leonard, M. D., Michaelides, E. E. and Michaelides, D. N. Substitution of coal power plant with renewable energy source - Shift of the power demand and energy storage, Energy Conversion and Management, 164, 2018, 27-35.

[4] Dmitrienko, M. A., Nyashina, G. S. and Strizhak, P. A. Major gas emission from combustion of slurry fuels based on coal, coal waste, and coal derivatives, Journal of Cleaner Production, 177, 2018, 284-301.

[5] Available at www.doe.gov.ph/overall-statistics-oncoal

[6] Available at www.doe.gov.ph/philippine-powerstatistcs

[7] Chelgani, S. C. and Hower, J. C. Relationship between noble metals as potential coal combustion products and conventional coal properties, Fuel, 226, 2018, 345-349.

[8] Behera, S. K., Meena, H., Chakraborty, S. and Meikap, B. C. Application of response surface methodology (RSM) for optimization of leaching parameters for ash reduction from low-grade coal, International Journal of Mining Science and Technology, 2018, Article in press.

[9] Luo, Y., Ma, S., Zhao, Z., Wang, Z., Zheng, S. and Wang, X. Preparation and characterization of whisker-reinforced ceramics from coal, Ceramics International, 43, 2017, 1-11.

[10] Yao, Z. T., Ji, X. S., Sarker, P. K., Tang, J. H., Ge, L. Q., Xia, M. S. and Xi, Y. Q. A comprehensive review on the application of coal fly ash, EarthScience Review, 141, 2015, 105-121.

[11] Singh, N., Mithulraj, M. and Arya, S. Influence of coal bottom ash as fine aggregates replacement on various properties of concrete: A review, Resources, Conservation and Recycling, 138, 2018, 257-271.

[12] Kaksonen, A. H., Boxall, N. J. Gumulya, Y., Khaleque, H. N., Morris, C., Bohu, T., Cheng, K. Y., Usher, K. M. and Lakaniemi, A. Recent progress in biohydrometallurgy and microbial characterization, Hydrometallurgy, 180, 2018, 725.

[13] Potysz, A., van Hullebusch, E. D. and Kierczak, J. Perspective regarding the use of metallurgical slags as secondary metal resources - A review of bioleaching approaches, Journal of Environmental Management, 219, 2018, 138-152.

[14] Gu, T., Rastegar, S. O., Mousavi, S. M., Li, M. and Zhou, M. Advances in bioleaching for recovery of metals and bioremediation of fuel ash and sewerage sludge, Bioresource Technology, 261, 2018, 428440.

[15] Ye, M., Li, G., Yan, P., Ren, J., Zheng, L., Han, D., Sun, S., Huang, S. and Zhong, Y. Removal of metals from lead-zinc mine tailing using bioleaching and followed by sulfide precipitation, Chemosphere, 185, 2017, 1189-1196.

[16] Potysz, A., Lens, P. N. L., van de Vossenberg, J., Rene, E. R., Grybos, M., Guibaud, G., Kierczak, J. and van Hullebusch, E. D. Comparison of $\mathrm{Cu}, \mathrm{Zn}$ and $\mathrm{Fe}$ bioleaching from $\mathrm{Cu}$-metallurgical slags in the presence of Pseudomonas fluorescence and Acidithiobacillus thiooxidans, Applied Geochemistry, 68, 2016, 29-52.

[17] Chen, S., Yang, Y., Liu, C., Dong, F. and Liu, B. (2015). Column bioleaching copper and its kinetics of waste printed circuit boards (WPCB) by Acidithiobacillus ferrooxidans. Chemosphere, 141, 162-168.

[18] Amiri, F., Mousavi, S. M., Yagjmaei, S. and Batari, M. Bioleaching kinetics of a spent refinery catalyst using Aspergillus niger at optimal conditions. Biochemical Engineering Journal, 67, 2012, 208217.

[19] Bakhtiari, F., Atashi, H., Zivdar, M., Seyedbagheri, S. and Fazaelipoor, M. H. Bioleaching kinetics of copper from copper smelter dust. Journal of Industrial and Engineering Chemistry, 17, 2011, 29 -35 .

[20] Pangayao, D. C., Gallardo, S. M., Promentilla, M. A. B. and van Hullebusch, E. D. Bioleaching of trace metals from coal ash using local isolate from coal ash ponds, 156, 2018, 03031.

[21] Sen, S. K., Das, M. M., Bandyopadhyah, P. and Dash, R. R. Green process using hot spring bacterium to concentrate alumina in coal fly ash, Ecological Engineering, 88, 2016, 10-19.

[22] Jujun, R., Xingjiong, Z., Yiming, Q., and Jian, H. A new strain for recovering precious metals from waste printed circuit boards, Waste Management, 34, 2014, 901-907.

[23] Singh, R., Bishnoi, N. R., Kirrolia, A. and Kumar, R. Synergism of Pseudomonas aeruginosa and $\mathrm{Fe} 0$ for treatment of hevy metal contaminated effluent using small scale laboratory reactor, Bioresource Technology, 127, 2013, 49-58.

[24] Jeremic, S., Beskoski, V. P., Djokic, L., Vasiljevic, B., Vrvic, M. M., Avdalovic, J., Cvijovic, G. G., Beskoski, L. S. and Nikodinovic-Runic, J. Interaction of tolerant heterotrophic microorganisms and iron oxidizing autotrophic bacteria from sulphidic mine environment during 
bioleaching experiments, Journal of Environmental Management, 172, 2016, 151-161.

[25] Lin, J-G. and Chen, S-Y. Influence of solid content on bioleaching of heavy metals from contaminated sediments by Thiobacillus spp., Journal of Chemical Technology and Biotechnology, 75, 2000, 649-656.

[26] Hu, G., Liu, G., Wu, D. and Fu, B. Geochemical behavior of hazardous volatile elements in coal with different geological origin during combustion, 233, 2018, 361-376.

[27] Stefaniak, S., Kmiecik, E., Miszczak, E., Szczepanska-Plewa, J. and Twarsowska, I. Leaching behavior of fly ash from co-firing of coal with alternative off gas fuel in powerplant boiler, 93, 2018, 129-144.

[28] Akar, G., Polat, M., Galecki, G. and Ipekoglu, U. Leaching behavior of selected trace metals in coal fly ash samples from Yenikoy coal-fired power plant, Fuel Processing Technology, 104, 2012, 5056.

[29] Skordas, G., Grmmelis, P., Prokopidou, M., Kakaras, E. and Sakellaropoulos, G. Chemical, leaching and toxicity characteristics of CFB combustion residue, Fuel, 88, 2009, 1201-1209.

[30] Sen, S. K., Das, M. M., Bandyopadhyah, P. and Dash, R. R. Green process using hot spring bacterium to concentrate alumina in coal fly ash. Ecological Engineering, 88, 2016, 10-19.

[31] Hassanien, W.A.G., Desouky, O. A. N. and Hussein, S. S. E. Bioleaching of some rare earth elements from Egyptian Monazite using Aspergillus fucuum and Pseudomonas aeruginosa, Walailak Journal of Science and Technology, 11, 2013, 809-823.

[32] Rasamiravaka, T., Labtani, Q., Duez, P. and El Jaziri, M. The formation of biofilms by Pseudomonas aeruginosa: A review of the natural and synthetic compounds interfering with control mechanism, BioMed Research International, 2015, $1-17$. 